\title{
(a) 5
}

ISSN 2450-6486

www.ehs-ss.pl

DOI: 10.38014/ehs-ss.2020.1.07

\section{Liudmyla NAUMENKO, Vitaliia MUNTIAN}

\section{The novel visualization techniques of teaching Ukrainian literature in the secondary school}

Der Lehrer soll mit der Zeit Schritt halten. A. Diesterweg

Introduction. Intensive development of the technology and society provokes a quick rise of standards to general education. The young progressive generation of children (generation $\mathrm{Z}$ ) perceives the world in a quite different way: it keeps pace with modern technologies, lays new paths, has thousands of network friends in the Internet. The real status quo does not suit young people; the only reality is too little for them and they create a virtual one. All these factors stimulate a progressive teacher to seek for more creative, consciously-oriented and interactive forms of teaching activities. The same is true with studying Ukrainian literature as a kind of art which requires innovative creative methods. As the prominent 
Ukrainian pedagogue V.A. Sukhomlynskyi states, "the first and foremost task of the teacher is to discover a creator in every pupil and orient him to independent, intellectual, and creative work" [1].

Previous research. The problem of visualization of the educational process has attracted attention of many scholars, pedagogues and teachers from different points of view: psychological - as an effective heuristic method of teaching on the basis of logical operations [2]; general pedagogical - as a means of developing student's critical thinking [3], intensification of student's cognitive activity on the basis of modern informative and telecommunication techniques [4-5], teaching by means of infographics technique [6]; methodological - while conducting pedagogical experiment of using schemes and other visual images during the lecture course in the pilot and control groups [7], etc.

Since the establishment of lingua-didactics and adjacent disciplines, like the methodology of teaching literature and lingua-cultural studies, the interest in the visualization techniques applicable for teaching languages and literature has also increased. The most recent explorations of this issue have revealed in the publications by Ukrainian L. O. Hapon (2019), M. Y. Tsymbaliuk [8-9] and foreign authors P. Dewi (2017), A. A. Nahari \& H. A. Alfadda (2016) [10-11], etc.

Nevertheless the visualization techniques in teaching languages have been widely explored in many aspects (traditional visual images, video, animation, computer-based techniques), the novel visual technologies and connected techniques, especially for teaching literature, have not been thoroughly studied yet. Our research is going to fill in this niche.

The purpose of the paper is to make a systemic analysis and description of the most useful, user-friendly, and effective visualization techniques for teaching Ukrainian literature in the secondary school. The objectives of the study are to define major recent visualization techniques applicable to teaching literature, possibility to use them in the secondary school, pro and contra of their usage in the classroom.

The methodology of the research takes into account the recent tendencies in pedagogy which direct educational process towards forming of spiritually rich and developed individual, establishing general cultural wealth, revealing of student's creative potential. There is the only possible way to solve these tasks by means of the newest pedagogical techniques aimed at the development of the creative capabilities of each student. As early as in 1950's E. Y. Golant spoke about the two models of teaching - passive and active [12]. The first one presupposes authoritative 
style of interaction, considering the student as an object of teaching, and the textbook as a main source of information and the 'right' knowledge. Accordingly, the major form of work is a lecture, the main forms of activity are explanation, demonstration, asking and answering questions, reading, writing, monologue speaking, reporting home tasks, etc. The active model puts the stress on the democratic style of teaching and interactive methods as a part of it. Accordingly, the teacher and students are equal parties of the process, they work in the regime of dialogue, the major forms of work are problem-solving and creative tasks, team and independent work, simulation of the real-life situations, and taskoriented communication. This model excludes the domination of one of the participants over the others or preference of one opinion over the rest; develops student's cognitive abilities, independence, and creative thinking. Besides, according to the second model, students study the fundamentals of democracy, civil communication with other people, the ability to make grounded decisions. Interactive methods of teaching also open opportunities for students to communicate with each other and a wide range of other people outside school. The role of the teacher is to monitor their activity and be an adviser in their intellectual and practical activity. The methods applied in the research comprise analysis and synthesis, comparison, demonstration, and modeling. The material is represented by novel teaching techniques from the point of view of their visual potential and capability to be applied at the lessons of literature in the secondary school.

Preliminary considerations. The term technique derives from Greek techne - 'art' and logos - 'to teach'. There is a great diversity of definitions of the term. From one point of view, it is a teaching management; from the other one, it is a particular means of the organisation of student's learning activity; from the third one, it is a set of methods for achieving the educational purpose. Techniques and methods can be differentiated according to two criteria - a guarantee of the final result and planning of the future. Thus, the pedagogical technique is a set of procedures which renew the teacher's professional activity and guarantees its planned final result. The methodology of teaching, in its turn, originates as a result of generalized experience and implementation of new teaching methods. The major difference is that the technique is planned due to concrete conditions and circumstances and is oriented at a certain, predicted result. The technique does not admit variability or searching activity; it requires permanent feedback and corrections in the process of its application [13]. 
The body. Visualization techniques which comprise "creation and representation of graphical images, texts or factual information by making it visual, and thus, more convenient for analysis and thinking over" [14] can be widely applied in modern Ukrainian school of different levels for teaching both language and literature. Among the novel visualization techniques, which have been recently introduced in teaching Ukrainian literature at the secondary school, there are interactive book, due to of tags, book trailer, lap-book, timeline, scribing, and comics. Each above mentioned visualization technique is considered in our work from the following points of view: a) essence and content; b) opportunity to be created and used with the help of tablets, mobile phones, PowerPoint, other gadgets or computer-added appliances; c) ways of application in the classroom study; d) influence on attention, intellect, and memory of students; e) capability to stimulate the student's learning activity; $f$ ) advantages and disadvantages; g) availability of Internet services.

The interactive book is an electronic appliance that turns a usual paper textbook into an effective visual resource. It can be loaded into the smartphone and by touching the screen one can activate it. The content of the interactive book comprises 3D models, audio- and video, computer graphics, animation that complete the text. Thus, each student who has

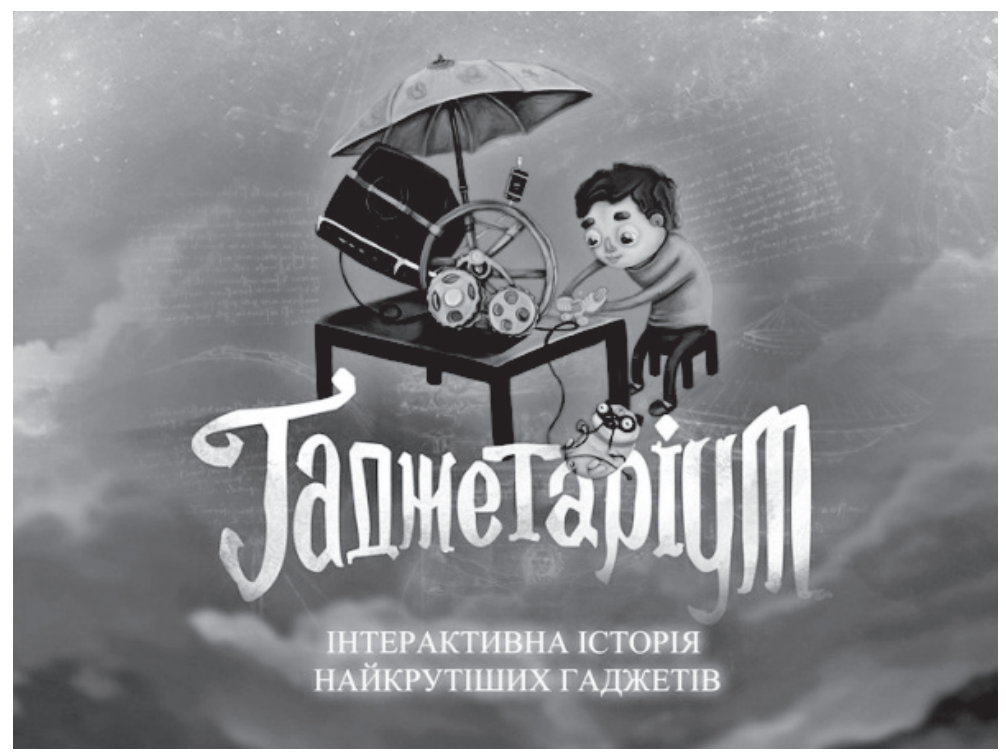

Fig. 1. The interactive book 'Gadgetaruim' by Publishing House 'Gutenbergz'. 
an access to the addition on the mobile phone can be both a listener and active participator of the events. Unfortunately, besides several interactive fairy tales books for younger children, there are practically no Ukrainian interactive textbooks for secondary school. The Publishing House 'Gutenbergz' in Odesa has started issuing such textbooks for schoolchildren-'Gadgetarium', 'Sherlock Holmes', 'History of Odesa' [15] which are supplied with interactive multimedia content. The interactive textbooks have such advantages over the paper ones as: additional functions of checking the student's knowledge, making one's own notes, access to the user's analytics of the school teachers and parents.

The cloud of tags or cloud of words is a visual representation of words on a single picture that can be used for visualization of terminology on a specific topic, and thus, facilitating its memorizing. It attracts the attention of students and makes them concentrate on certain notions and concepts. This visual object combines both visible images and content, arouses interest to the text, and optimizes the work with information. Some methodologists consider a cloud of tags as an effective means for mastering key notions of the text. Making definitions of words and establishing

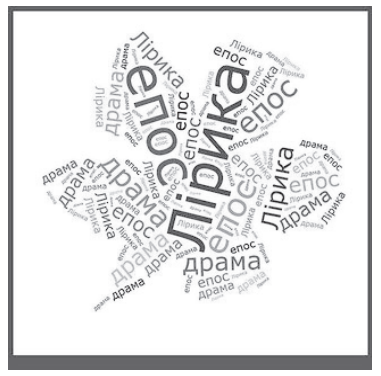

1.

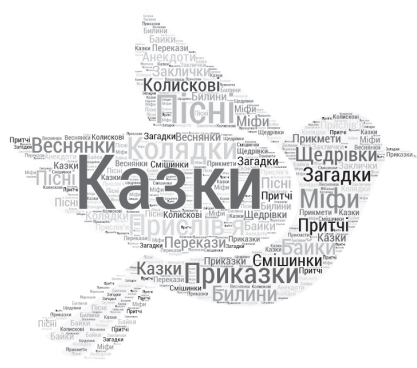

2

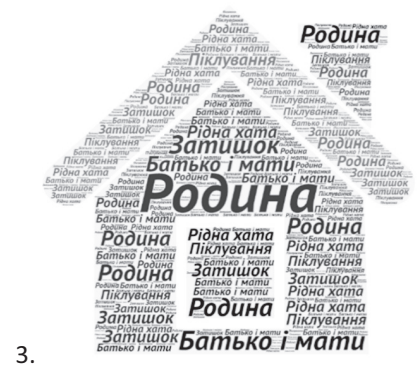

Fig. 2. Clouds of tags 'Kinds of Literature', 'The Charming Desna River' by Olexander Dovzhenko, 'Oral Ukrainian Folklore'. 
links between them demand student's intellectual and memory efforts, especially if the work is performed in a form of a dialogue or discussion.

The picture that bears words is not necessarily has the form of a cloud; it can be represented in any image, e.g., in a form of a flower, house, bird, fish, sun, etc. For example, the following clouds of tags represent the topics: 'Kinds of Literature' and 'Oral Ukrainian Folklore', the story 'The Charming Desna River' by Olexander Dovzhenko that are taught in the 5 th form.

The advantage of the cloud of tags technique is attractiveness and visibility of key notions of literary works, the additional challenge is the necessity to possess some computer graphics or drawing skills for creation of such visual images.

The book trailer is a short video clip, 3-5 minutes long, that reproduces in a free form the plot of a well-known novel or story and compliments the oral narration about the author, hero, historic event, or literary work. It also helps with presentations of information on a particular topic. The peculiarity of a booktrailer is a specific representation of information that can provoke interest and intrigue of the audience. Moreover, all the group members can be involved in making a trailer. The major problem is whether students possess the necessary skills in video recording and montage. For creating such video clips there are special programs that are installed on personal computers and mobile phones, i.e.: Windows Movie Maker (for beginners) [16], Vegas Pro (for more advanced users) [17], PowerDirector Video Editor (for those who usually uses mobile appliances) [18].

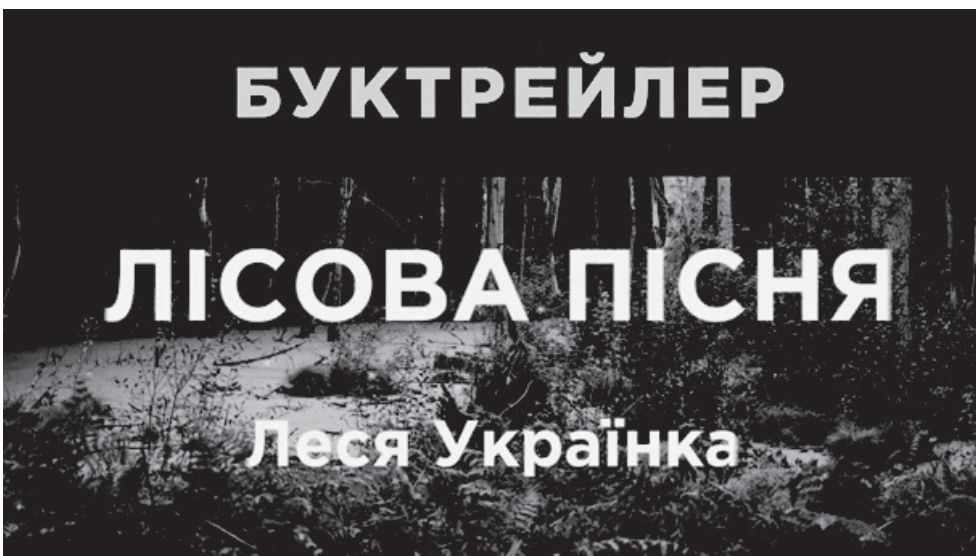

Fig. 3. Book trailer on the plot of the poem 'The Forest Song' by Lesia Ukrainka. 
The lap-book is a technique of self-making thematic paper file with pockets and movable elements. It is usually present at the final stage of the student's individual work or research. To create a lap-book it necessary to have a cardboard, paper sheets, strips for quilling, colour pencils, pens and markers, scissors, glue, scotch, stapler, decoration elements - stickers, photos, drawings, small objects, etc. A lap-book is made in an arbitrary form; it demands imagination and creativity. The main advantage of this technique is systemic structuring of information and developing of student's creative potential. The main disadvantage of it is time-consuming preliminary preparation.

The following lap-book illustrates the major stages in the biography and creative work of the prominent Ukrainian poet Taras Shevchenko.

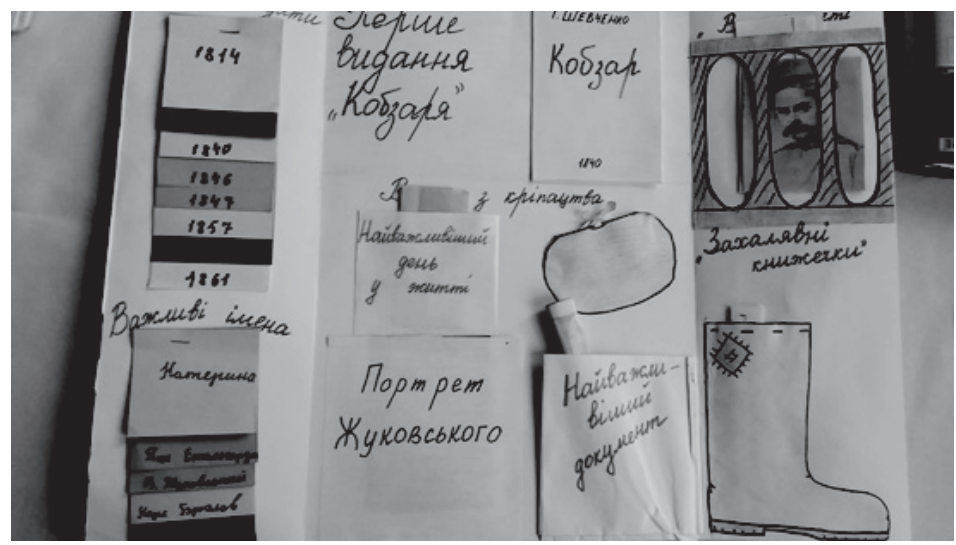

Fig. 4. Lap-book on the topic "The biography and creative work of Taras Shevchenko".

The timeline (the former name is time arrow) is a graphical representation of periods and dates of important historical events, author's biography or development of a novel fable. The timeline is well applicable to the stories built on the chronological principle. Timeline technique also permits to reconstruct chronology and logic of events, and thus, involving the student's cognitive potential.

For example, while studying the epic poem 'The Tale of Bygone Times' in the 5th form a teacher presents the following timeline to illustrate the period of existence of the state of Kyiv Rus (KR / KP), the date of historical battle between Pechenigs and Rus warriors, and how much time has passed since then. Each segment of the timeline equals to the period of 100 years. 


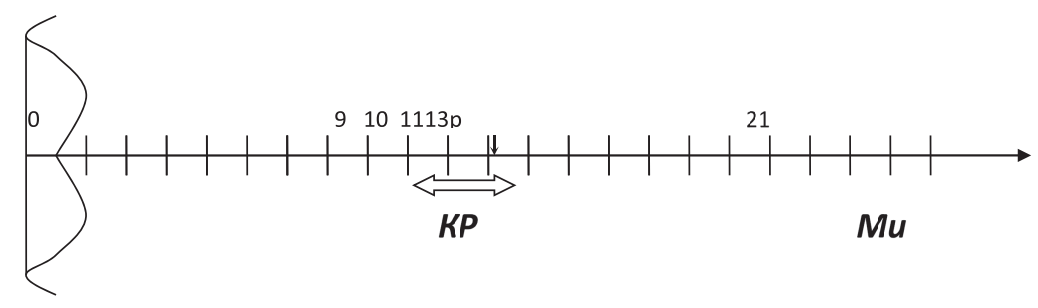

Fig. 5. Timeline to the epic poem 'The Tale of Bygone Times'.

The similar timelines can be drawn through online web-services Time.Graphics, Sutori, Tline, Timeline Creator [19-22]. In Timeline Creator the interface of the program permits to reconstruct up to six timelines at the same time which allows comparing the analysed events. The dates are also supported with the text commentary and multimedia supplement, i.e.: photos, audio-, and video. The program Timeline Maker Professional [23] has a simplified student's version that builds a timeline automatically. For this purpose a user loads the data into the table, as in Microsoft Excel, and inputs the task with the mouse.

This technique is especially useful for memorizing chronology of events, performing operations of comparison or contrast, and making logical conclusions. It can be also involved in presenting new topics or checking already mastered knowledge. The disadvantage of this technique is the necessity to possess a certain level of computer literacy and practical skills of operating particular computer programs for both teachers and students.

The scribing is a new technique of presentation created by British painter Andrew Park for the British Organisation of Scientific Knowledge. Such presentation is accompanied by the speaker's drawings with felt-tip pen on the white blackboard. Thus, the audience simultaneously listens and watches the same information presented in different sign systems. So, scribing is a kind of art that represents one's own speech in drawings in real-time. Scribe-presentation represents key notions of the report and links between the major statements. The wide-spreading of this technique is due to the fact that a human brain partially thinks by concrete images represented in imagery thinking.

One of the first pedagogues who decided to apply scribing to the teaching process was the American teacher Paul Bohush who managed to prove its effectiveness [24]. Among the advantages of this technique one can mention the following: better attention of the audience, 


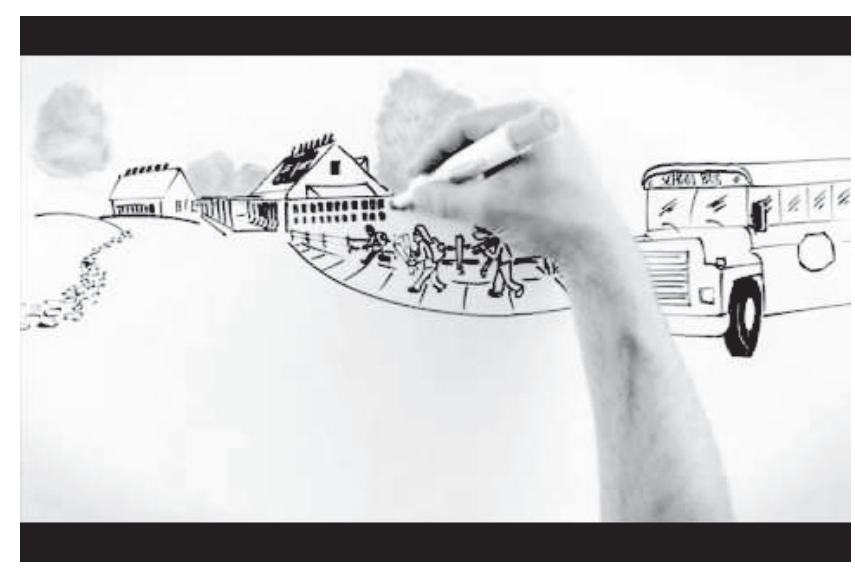

\section{Fig. 6. Illustration of scribing technique.}

better understanding of the presenter, better perception and analysis of information, easier remembering of key issues, development of imagery thinking.

There two major kinds of scribing - scribe-presentation and video scribing. The first one is more widely-spread as it accompanies a speaker's talk with simple schemes, drawings, and charts. Video scribing is a more dynamic kind as it uses illustrations, graphs, diagrams, comics, etc. in footage especially by means of the programs PowerPoint, GoAnimate, Animaker [25-27]. The major problem is possessing skills in drawing and computer technologies.

The comics (E. comic - 'funny'), more rare name sequential art (which means 'to be continued'), is a technique of creating a sequence of drawings with short texts that composes consistent and coherent story. Nevertheless the first comics appeared in the $19^{\text {th }}$ century in U.S. newspapers, their usage as a teaching technique has not a very long history. The key elements of comics include panels (boxes), balloons (speech bubbles), text (lines), and characters themselves. Balloons are convex spatial containers of information that are related to a character. The main means of creating comics are writing, drawing, and colouring. As M. Manno states, comics and graphic novels are motivating, support struggling readers, enrich the skills of accomplished readers and are highly effective at teaching sometimes dull or dry material in subject areas such as science or social studies [28]. Josh Elder, the founder and co-president of 'Reading with Pictures' association, sums up the strengths of comics as an educational tool in 3 E's: engagement, efficiency, effectiveness [29]. 


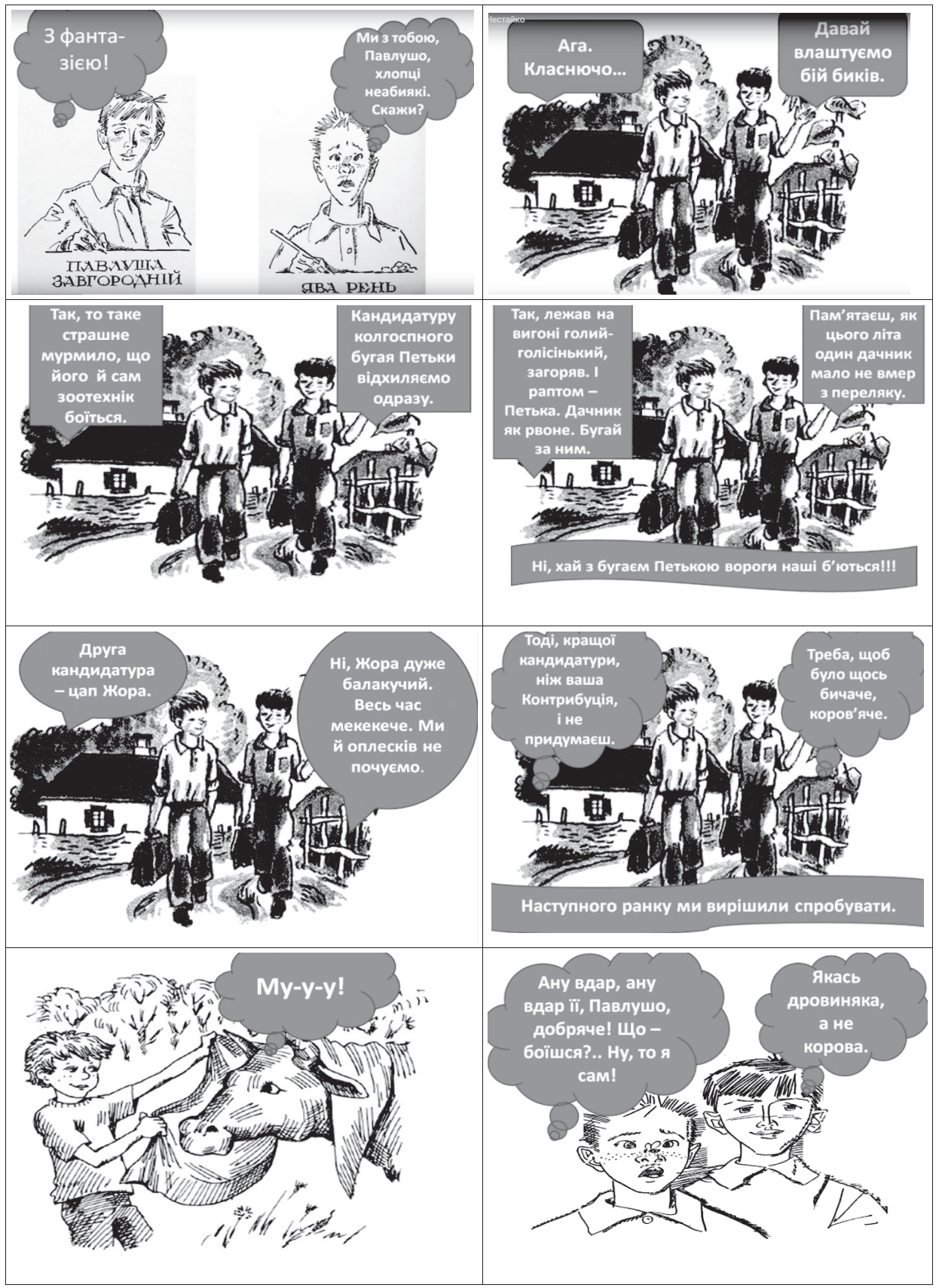




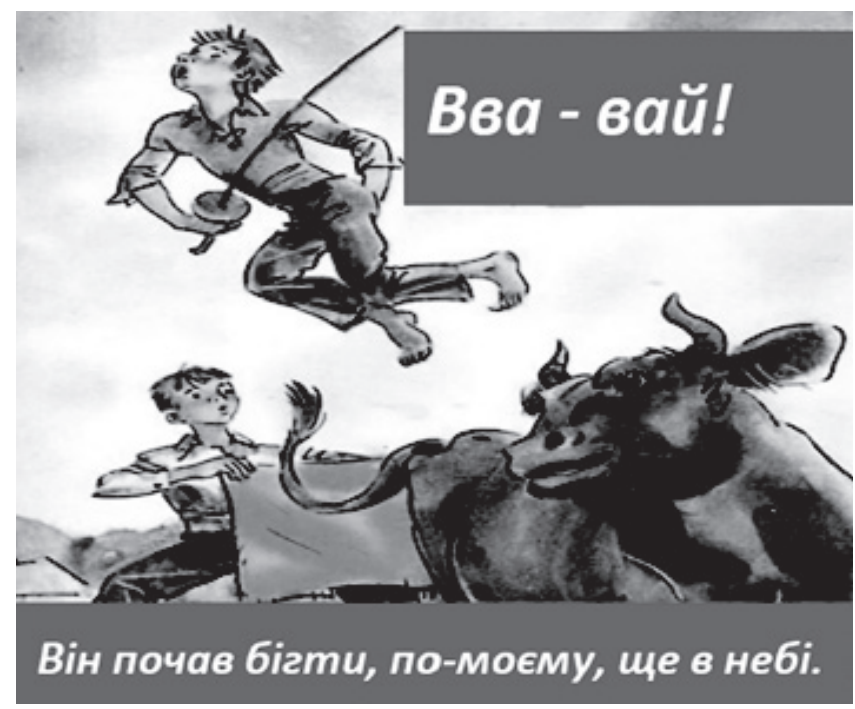

Fig. 7. Fragment of comics 'The Toreadors from Vasiukivka Village' by Vsevolod Nestaiko.

Here is a fragment of the comic book 'The Toreadors from Vasiukivka Village' by Vsevolod Nestaiko, which is considered to be one of the most popular stories among Ukrainian young people.

The fragment of comics in Fig. 7 presents a well-known story by Vsevolod Nestaiko about adventures of two friends during their summer vacations in the Ukrainian village that is full of funny situations and humorous dialogues, and has a didactic result. The technique of comics is very attractive, especially for younger students, from different points of view, first of all, it represents an interesting plot, helps to review the already studied literary work (or, vice versa, introduce it), brings positive, relaxing element to the classroom routine. Besides, comics are fashionable and popular in the whole world too. Students like to read comics because they develop their imagination and fantasy, logic of thinking, give the opportunity to experience adventures of their favourite heroes once again. They can be also used for performing different exercises, like filling in the blanks with words or cues, ranging the boxes in proper order, writing answers to certain cues or composing essays to some of them. Students can perform the task of presenting fragments of the literary work or the author's biography in this genre by themselves too. One disadvantage of this visual technique is the risk of student's getting used to small texts instead of full literary works, the other one is that comics can be only used 
as supplementary means to fill in small pauses during the lesson, a kind of 5-minutes relaxation.

The helpful online computer-added instruments for creating comics are the following: MakeBeliefsComix with a great number of patterns and symbols suitable (recommended for beginners and younger learners) [30]; Toondoo and Stripcreator which permit to make comics from one's own photos or to use the gallery of ready-made personages and to add or edit texts easily [31-32] MediBangPaint with more than 1000 instruments (paintbrushes, fonts, backgrounds, etc.) for creating pictures [33] and some others like Pixton, MyStoryBook [34-35], etc.

Conclusions. The new tendencies which direct the educational process towards forming a spiritually rich and developed individual, establishing general human cultural wealth, revealing student's creative potential motivate Ukrainian teachers to seek innovative and efficient methods and techniques of teaching. Such novel visualization techniques as: interactive book, cloud of tags, book trailer, lap-book, timeline, scribing, and comics are among them. The authors have considered each visualization technique from different points of view: a) essence and content; b) opportunity to be created and used with the help of tablets, mobile phones, PowerPoint, other gadgets or computer-added devices; c) ways of application in the classroom study; d) influence on attention, intellect, and memory of students; e) capability to stimulate the student's learning activity; f) advantages and disadvantages; g) availability of Internet services which can be helpful for student's creative activity (project, teamwork or individual). The conducted analysis permits to make the following conclusions: there is no universal visualization technique applicable for all cases; each technique has both strengths and weaknesses; application of a particular technique should agree with the topic of the lesson, its purpose, and form of work (individual, pair, group, project); the best way is to apply visualization techniques in their combination, thus making the classroom activity more interesting and diversified.

Application and further studies. The results of the research can be valuable to pedagogues and teachers who are interested in modern teaching techniques, visualization as well, and would like to apply them into the process of teaching literature. The paper opens a perspective for detailed study of the content and a set of instruments of computer programs and Internet services on visualization of verbal information for their further implementation at the lessons of Ukrainian literature. 


\section{References:}

1. Сухомлинський В. А. Серце віддаю дітям. К.: Радянська школа, 1969. 244 с.

2. Кротова И., Камоза Т., Донченко Н. Метод визуадизации в системе инновационного обучения. Высшее образование в России. №4, 2008. С. 164-167.

3. Shatri K., Buza K. The Use of Visualization in Teaching and Learning Process for Developing Critical Thinking of Students. European Journal of Social Sciences. Education and Research. Vol. 4. Issue 1, 2017. P. 71-74.

4. Klerkx J., Verbert K., Duval E. Enhancing Learning via Visualization Techniques. P. 1-42. URL: https://core.ac.uk/download/pdf/34578677.pdf

5. Коленкина И. Н. Визуализация в обучении. URL: http://lib.teacher.msu.ru/ pub/3052

6. Сорока О. Г., Васильева И. Н. Визуализация учебной информации, 2015. URL: https://elib.bspu.by/bitstream/doc/10693/1/Soroka_PS_12_2015.pdf

7. Булгакова О. С., Буркова С. А. Активный метод визуализации и структурирования информации в педагогике высшей школы как элемент психофизиологический защиты. Современные наукоёмкие технологии. № 1, 2016. С. 69-73.

8. Гапон Л. О. Дива візуалізації, або як зробити знання видимими, а уроки літератури - незабутніми. Блог 24.04.2019. URL:

9. Цимбалюк М. Ю. Використання сучасних програм забезпечення для візуалізації навчального матеріалу з української літератури у загальноосвітніх навчальних закладах. URL: https:/www.ito.vspu.net/ konference15/15_11/Tcymbalyuk.pdf

10. Dewi P. Teaching Reading to Young Learners through Visualization Strategy. First English Language and Literature Conference, 2017. P. 178-182. URL: https:// jurnal.unimus.ac.id

11. Nahari A. A., Alfadda, H. A. From Memorising to Visualizating: the Effect of Using Visualization Strategies to Improve Students' Spelling Skills. English Language Teaching. Vol. 9. № 6, 2016. P. 1-18.

12. Голант Е. Я. Методы обучения в советской школе. Москва: ГУПИ МП РСФСР, 1957. $151 \mathrm{c}$.

13. Сисоєва С. О. Педагогічні технологї: коротка характеристика сутнісних ознак. Педагогіка, 2006. URL: http://library.kubg.edu.ua/images/stories/ Departaments/biblio/vydannya/Bib_pokaz_Sisoeva.pdf

14. 9 прийомів візуалізації для викладання на уроці. Практичні прийоми. Всеукраїнська інтернет-конференція “На уроці”. URL: https:/naurok.com.ua/

15. Windows Movie Maker. URL: https://www.movavi.ru/support/how-to/

16. Vegas Pro. URL: https://www.vegascreativesoftware.com/ru

17. PowerDirector Video Editor. URL: https://www.cyberlink.com/stat/ product/ CyberLink_app/PowerDirector-mobile/enu/PowerDirector-mobile.jsp

18. Google online service. URL: https://google.it/

19. Time.Graphics. URL: https://time.graphics/ru/ 
20. Sutori. URL: https://www.sutori.com/

21. Tline. URL: https://tline.io/

22. Timeline Creator. URL: http://timeline.ur.jhu.edu

23. Timeline Maker Professional. URL: http://www.timelinmaker.com

24. Bohush, Paul. Scribing. URL: http://virtus.conference-ukraine.com.ua/Journal127. pdf

25. Power Point. URL: https://office.live.com/start/PowerPoint.aspx?omkt=uk-UA

26. GoAnimate. URL: https://goanimate.com/

27. Animaker URL: https://www.animaker.com/

28. Manno, M. Comics in the Classroom. Blog. Aug 04 2014. URL: https://teach.com/ blog/why-comics/

29. Elder, Josh. One-Shots: Josh Elder and Reading with Pictures. URL: https:// gapersblock.com/booksclub/2010/23/one_shots_josh_elder/

30. MakeBeliefsComix. URL: https://www.makebeliefscomix.com

31. Toondoo. URL: https://www.toondoo.com

32. Stripcreator. URL: https://www.stripcreator.com

33. MediBangPaint. URL: https://www.medibangpaint.com

34. Pixton. URL: https://www.pixton.com

35. MyStoryBook. URL: https://www.mystorybook.com

\section{Transliteration of References:}

1. Sukhomlynsky, V. A. (1969). Sertse Viddayu Ditiam. K.: Radianska shkola. 244 p.

2. Krotova, I., Kamoza, T., Donchenko, N. (2008). Metod vizualizatsii v systeme innovatsionnogo obucheniya. Vyssheye obrazovaniye v Rossii. №4. P. 164-167.

3. Shatri, K., Buza, K. (2017). The Use of Visualization in Teaching and Learning Process for Developing Critical Thinking of Students. European Journal of Social Sciences. Education and Research. Vol. 4. Issue 1. P. 71-74.

4. Klerkx, J., Verbert, K., Duval, E. Enhancing Learning via Visualization Techniques. P. 1-42. URL: https://core.ac.uk/download/pdf/34578677.pdf

5. Kolenkina, I. N. Vizualizatsiya v obuchenii. http://lib.teacher.msu.ru/pub/3052

6. Soroka, O. G., Vasilieva, I. N. (2015). Vizualizatsiya uchebnoi informatsii. URL: https://elib.bspu.by/bitstream/doc/10693/1/Soroka_PS_12_2015.pdf

7. Bulgakova, O. S., Burkova, S. A. (2016). Aktivnyi metod vizualizatsii i strukturirovaniya informatsii v pedagogike vyssheyi shkily kak element psikhofizicheskoi zashchity. Sovremenniuye naukoemkiye tekhnologii. № 1. 69-73.

8. Hapon, L.O. (2019). Dyva vizualizatsiyi, abo yak zrobyty znannia vydymymy, a uroky literatury - nezabutnimt. Blog 24.04.2019. URL:

9. Tsymbaliuk, M. Y. Vykorystannia suchasnykh program zabezpechennia dlia vizualizatsiyi navchalnogo materialu $\mathrm{z}$ ukrayinskoyi literatyry $\mathrm{u}$ zagalnoosvitnikh navchalnykh zakladakh. URL: https://www.ito.vspu.net/ konference15/15_11/Tcymbalyuk.pdf

10. Dewi, P. (2017). Teaching Reading to Young Learners through Visualization Strategy. First English Language and Literature Conference, 2017. P. 178-182. URL: https://jurnal.unimus.ac.id 
11. Nahari, A. A., Alfadda, H. A. (2016). From Memorising to Visualizating: the Effect of Using Visualization Strategies to Improve Students' Spelling Skills.

"English Language Teaching". 9(6). 1-18.

12. Golant, E. Y. (1957). Metody obucheniya v sovetskoyi shkole. Moskva: GUPI MP RSFSR. $151 \mathrm{p}$.

13. Sysoyeva, S. O. (2006). Pedagogichni tekhnologiyi: korotka kharakterystyka sytnisnykh oznak. Pedagogika. URL: http://library.kubg.edu.ua/images/stories/ Departaments/biblio/vydannya/Bib_pokaz_Sisoeva.pdf

14. 9 pryyomiv vizualizatsiyi dlia vykladannia na urotsi. Praktychni pryyomy. Vseukrayinska internet-konferetsiya "Na urotsi". URL: https://naurok.com.ua

15. Windows Movie Maker. URL: https://www.movavi.ru/support/how-to/

16. Vegas Pro. URL: https://www.vegascreativesoftware.com/ru

17. PowerDirector Video Editor. URL: https://www.cyberlink.com/stat/ product/ CyberLink_app/PowerDirector-mobile/enu/PowerDirector-mobile. jsp

18. Google online service. URL: https://google.it/

19. Time.Graphics. URL: https://time.graphics/ru/

20. Sutori. URL: https://www.sutori.com/

21. Tline. URL: https://line.io/

22. Timeline Creator. URL: http://timeline.ur.jhu.edu

23. Timeline Maker Professional. URL: http://www.timelinmaker.com

24. Bohush, Paul. Scribing. URL: http://virtus.conference-ukraine.com.ua/Journal127. pdf

25. Power Point. URL: https://office.live.com/start/PowerPoint.aspx?omkt=uk-UA

26. GoAnimate. URL: https://goanimate.com/

27. Animaker URL: https://www.animaker.com/

28. Manno, M. (2014). Comics in the Classroom. Blog. Aug 04 2014. URL: https:// teach.com/blog/why-comics/

29. Elder, Josh. (2010). One-Shots: Josh Elder and Reading with Pictures. URL: https://gapersblock.com/booksclub/2010/23/one_shots_josh_elder/

30. MakeBeliefsComix. URL: https://www.makebeliefscomix.com

31. Toondoo. URL: https://www.toondoo.com

32. Stripcreator. URL: https://www.stripcreator.com

33. MediBangPaint. URL: https://www.medibangpaint.com

34. Pixton. URL: https://www.pixton.com

35. MyStoryBook. URL: https://www.mystorybook.com

Authors

Naumenko Liudmyla

Doctor of Philology, Associate Professor,

Professor of the Department of

Methodology of Teaching Ukrainian

and Foreign Languages, 
Institute of Philology,

Taras Shevchenko National University of Kyiv,

Kyiv, Ukraine

E-mail:v-naumenko@ukr.net

orcid.org/0000-0002-4325-1673

Muntian Vitaliia

Student,

Institute of Philology,

Taras Shevchenko National University of Kyiv,

Kyiv, Ukraine

E-mail: vitalia_m@i.ua

orcid.org/0000-0002-1034-411X

Abstracts

NAUMENKO LIUDMYLA, MUNTIAN VITALIIA. Nowatorskie techniki wizualizacji nauczania literatury ukraińskiej w szkole średniej. Artykut jest poświęcony problemowi transformaciji procesu nauczania w szkole średniej na bardziej interaktywny, produktcyjny $i$ efektywny poprzez zastosowanie technik wizualizacji różnych formatów: wizualnych obrazów papierowych, zasobów elektronicznych $i$ internetowych. Celem badań jest określenie i scharakteryzowanie najbardziej przyjaznych dla użytkownika technik wizualizacyjnych odpowiednich do nauczania literatury w szkole średniej. Główna uwage zwraca się na sposoby dywersyfikacji obrazowej reprezentacji informacji werbalnej $i$ merytorycznej na lekcjach literatury ukrainskiej. Autorzy zajmuja sie takimi technikami wizualizacji jak: interaktywna ksią̇ka, chmura tagów, booktrailer, lap-book, timeline, pisanie, komiks. Każda technika wizualizacji jest rozpatrywana z następujacych punktów widzenia: a) istota i treść; $b$ ) możliwość tworzenia $i$ wykorzystywania za pomoca tabletów, telefonów komórkowych, PowerPoint'ów, innych gadżetów lub urządzeń dodawanych do komputera; c) sposoby zastosowania w nauce w klasie; d) wptyw na uwage, intelekt i pamięć uczniów; e) zdolność do stymulowania aktywności edukacyjnej ucznia; f) zalety $i$ wady; g) dostępność ustug internetowych, które moga być pomocne w pracy twórczej ucznia (projektowej, zespołowej lub indywidualnej). Artykuł otwiera perspektywe dla dokładnej analizy treści i narzędziowemu programów komputerowych i serwów internetowych $z$ wizualizacji werbalnej informacji dla ich dalszego wdrażania w procesie 
nauczania oraz prowadzenia eksperymentu pedagogicznego na lekcjach literatury ukrainskiej.

Stowa kluczowe: technika wizualizacji, obraz, środki nauczania, program komputerowy, serwis internetowy, literatura ukraińska

НАУМЕНКО ЛЮДМИЛА, МУНТЯН ВІТАЛІЯ. Новітні технології візуалізації у викладанні української літератури в середній школі. Стаття присвячена проблемі перетворення навчального процесу в середній школі на більш інтерактивний, продуктивний та ефективний за допомогою різних типів технологій візуалізаціи: традиційних паперових зображень, електронних та інтернет-ресурсів. Метою дослідження є визначення та опис характерних особливостей найбільш зручних у користуванні технологій візуалізацій, які придатні для викладання літератури в середній школі. Основна увага приділяється способам диверсифікації візуальних зображень вербальної та фактичної інформації на уроках украӥнської літератури. Автори зосереджують свою увагу на таких технологіях візуалізації, як: інтерактивна книга, хмара слів, буктрейлер, лепбук, шкала часу, скрайбинг та комікс. Кожна технологія візуалізації розглядається у плані: а) суті та змісту; б) можливості створення і застосування з допомогою ноутбуку, мобільного телефону, PowerPoint, інших гаджетів та комп'ютерних додатків; в) методів застосування на уроках; г) впливу на увагу, інтелект та пал'ять учнів; д) здатності стилулювати навчальну діяльність учнів; ж) переваг та недоліків; з) наявності інтернет-сервісів, що сприяють розвитку творчої діяльності учнів (проектної, групової та індивідуальноі). Стаття відкривае перспективу детального вивчення змісту та інструментарію комп'ютерних програм та інтернет-сервісів з візуалізації вербальної інформацї̈ для їх подальшого практичного застосування на уроках украӥнської літератури.

Ключові слова: технологія візуалізації, зображення, засоби навчання, коми'ютерна програма, інтернет-сервіс, украӥнська література.

\section{НАУМЕНКО АЮДМИЯА, МУНТЯН ВИТАЯИЯ. Новейшие технодогии визуадизации в преподавании украинской ди- тературы в средней школе. Статья посвящена проблеме прев-} ращения учебного процесса в средней школе в более интерактивный, продуктивный и әффективный с помощю различных технологий визуализации: традиционных изображений на бумаге, әлектронных и интернет-ресурсов. Цель исследования - определение и описание 
характерных особенностей наиболее удобных в использовании технологий визуализациии, которые пригодны для преподавания литературь в средней школе. Основное внимание уделяется способам диверсификации визуальных изображений вербальной и фактической информации на уроках украинской литературь. Авторь сосредотачивают свое внимание на таких технологиях визуализици, как: интерактивная книга, облако слов, буктрейлер, лепбук, шкала времени, скрайбинг и комикс. Каждая технология визуализациии рассматривается в плане: а) сути и содержания; б) возможности создания и применения с помощью ноутбука, мобильного телефона, PowerPoint, других гаджетов и компьютерньх приложений; в) методов применения на уроках; г) влияния на внимание, интеллект и палять учеников; д) возможности стимулировать учебную деяльность учеников; ж) преилущесть и недостатков; з) наличия интернет-сервисов, которые способствуют развитию творческой деяльности учеников (проектной, групповой и индивидуальной). Статья открывает перспективу детального изучения содержания и инструментария компьютерных програм⿻ и интернет-сервисов визуализацчии вербальной информацци для их дальнейшего использования на уроках украинской литературы.

Ключевье слова: технология визуализации, изображение, средства обучения, компьютерная программа, интернет-сервис, украинская литература.

NAUMENKO LIUDMYLA, MUNTIAN VITALIIA. The novel visualization techniques of teaching Ukrainian literature in the secondary school. The paper is devoted to the problem of making educational process in the secondary school more interesting, productive, and effective by means of using visualization techniques of different formats: visual paper images, electronic and Internet resources. The aim of the research is to determine and characterize the most user-friendly visualization techniques suitable for teaching literature in the secondary school. The major attention is paid to the ways of diversification of imagery representation of verbal and factual information at the lessons of the Ukrainian literature. The authors dwell on such visualization techniques as: interactive book, cloud of tags, book trailer, lap-book, timeline, scribing, and comics. Each visualization technique is considered from the following points of view: a) essence and content; b) opportunity to be created and used with the help of tablets, mobile phones, PowerPoint, other gadgets or computer-added appliances; $c$ ) ways of application in classroom study; d) 
influence on attention, intellect, and memory of students; e) capability to stimulate the student's learning activity; f) advantages and disadvantages; g) availability of Internet services which can be helpful for student's creative activity (project, teamwork or individual). The paper opens a perspective for detailed study of the content and a set of instruments of computer programs and Internet services on the visualization of verbal information for their further implementation at the lessons of the Ukrainian literature.

Keywords: visualization technique, image, means of teaching, computer program, Internet service, Ukrainian literature. 